\title{
Crop photosynthesis, respiration and dry matter production of maize
}

\author{
W. LOUWERSE, L. SIBMA \& J. VAN KLEEF \\ Centre for Agrobiological Research, P.O. Box 14, NL 6700 AA Wageningen, Netherlands
}

Received 21 September 1989; accepted 30 November 1989

\begin{abstract}
Above-ground net photosynthesis and respiration of a maize crop (Zea mays L.) was determined in the field during the growing season (mid June - end of October) at regular intervals ( 1 à 2 weeks) at two temperatures $\left(12.5\right.$ and $22.5^{\circ} \mathrm{C}$ ) by measuring the $\mathrm{CO}_{2}$ uptake or release in mobile crop enclosures. The actual growth rate of the crop was determined from fortnightly harvests. Temperature dependence of photosynthesis was highest in the early (till mid July) and very late (begin October) stages of crop growth, showing a reduction of about $50 \%$ at the higher irradiances $\left(>400 \mathrm{~W} \mathrm{~m}^{-2}\right)$. In the period of major dry matter production (mid July-September) the reduction was only 12-15\%. Assuming maintenance respiration to become constant for cobs and grain exceeding a yield of $1000 \mathrm{~kg} \mathrm{ha}^{-1}$ and for stems exceeding $2500 \mathrm{~kg} \mathrm{ha}^{-1}$, the measured and calculated dark respiration at $22.5^{\circ} \mathrm{C}$ matched fairly well. At $12.5^{\circ} \mathrm{C}$ the calculation, using the same assumtions, overestimated significantly dark respiration during the first part of the growing period. The carbon balance sheet showed that from the total amount of $\mathrm{CO}_{2}$ absorbed by the crop (equivalent to $30.7 \mathrm{t} \mathrm{DM} \mathrm{ha}^{-1}$ ), $30 \%$ was lost by above-ground respiration and $50 \%$ was invested in above-ground harvestable material. The remaining $20 \%$ is assumed to be transported to plant parts under the ground. Substantial losses of dry matter at the end of the growing season did not occur.
\end{abstract}

Keywords: Zea mays L., dry matter distribution, gross photosynthesis, net photosynthesis, respiration, growth respiration, maintenance respiration

\section{Introduction}

Development, growth and yield of a crop is the result of an interactive response of plants to environmental conditions: temperature, irradiance, water and nutrient supply. For a maize crop, temperature strongly influences early leaf development, growth and duration of the growth cycle. The effects of temperature on development, dry matter production and allocation, and quality of forage maize have been studied extensively (Struik, 1983).

Low soil and air temperatures in N.W. Europe affect germination, seedling growth and leaf appearance to such an extent that full soil cover by the canopy is 
delayed until early July (Sibma, 1977). As a consequence, relatively high levels of irradiance in early summer coincide with an incomplete soil cover.

Photosynthesis and respiration of maize plants increase with temperature (Duncan \& Hesketh, 1968). Net photosynthesis, however, increases less than the rate of development and the shortening of the growth duration. The ultimate effect on crop yield will also depend on the seasonal pattern of photosynthetically active radiation (PAR). In N.W. Europe, daily radiation drops progressively during the grain-filling phase, due to shortening days and a lower angle of incident sunlight. Struik et al. (1985) found in a greenhouse experiment that under these light conditions a rise in temperature after the 8-leaf stage reduced final dry matter yield because development rate was enhanced more than growth rate.

To improve insight into limitations for growth and yield of a maize forage crop under temperate climatic conditions, whole crop photosynthesis and respiration was studied in a field situation. In particular the conditions which cause a net gain or loss of dry matter in the period close to maturation of the crop are of importance for assessing the optimum harvest date of forage crops. The seasonal pattern of crop photosynthesis and respiration was determined, as well as the effects of temperature and light level in the different growth phases. The theoretical values of the coefficients for growht and maintenance respiration (Penning de Vries et al., 1989) were used to estimate the fraction of the biomass taking part in the maintenance processes. In addition, from the measured photosynthesis and respiration and the dry matter determination at various intermediate harvests, a carbon balance of the plant/soil-system was derived.

\section{Materials and methods}

\section{Crop data and equipment}

A maize crop (Zea mays L., cv. LG 11) was grown at a plant density of $10-11 \mathrm{~m}^{-2}$ on a sandy soil near Wageningen. The crop was sown on 1 May 1985 and well supplied with nutrients by adequate fertilization. Water shortage did not occur. Net photosynthesis, respiration and transpiration of the maize crop were determined from 17 June until the end of October 1985.

The actual growth rate of the crop was determined from fortnightly harvests of 4 plots with an area of $10.5 \mathrm{~m}^{2}$. At each harvest, leaf area, fresh and dry weight of leaves, stems and cobs (husk + spindle + kernels) were determined. C content in the total biomass was determined by micro-elemental analysis.

The exchange of $\mathrm{CO}_{2}$ and water vapour of 2 enclosed plots with an area of 80 $\mathrm{cm} \times 80 \mathrm{~cm}$ was measured at two different temperatures $\left(12.5\right.$ and $\left.22.5^{\circ} \mathrm{C}\right)$. The measurements were done with a mobile equipment as described before (Louwerse $\&$ Eikhoudt, 1975; Louwerse, 1980). The enclosure consisted of a transparent 'perspex' chamber, sealed onto a metal frame in the soil. The temperature in the chambers was controlled by an airconditioning unit. A pressure head of $300-400 \mathrm{~Pa}$ in the plant chamber and a layer of $3-5 \mathrm{~cm}$ of fine gravel on the soil prevented the interference of soil respiration and evaporation. Gas exchange was determined continu- 
ously using an open system, by measuring both the $\mathrm{CO}_{2}$ and $\mathrm{H}_{2} \mathrm{O}$ concentration in the ingoing and outgoing air by infra-red gas analysis and the air flux through the chambers. The $\mathrm{CO}_{2}$ concentration in the enclosures was maintained between 320 and $350 \mu 11^{-1}$ during daytime by adding $\mathrm{CO}_{2}$ from a gas cylinder as required. During night time an occasional overshoot occurred. Temperature was monitored by copper/constantan thermocouples and the humidity with capacitive hygrometers (Vaisala probes).

The total global radiation was measured outside the chamber with a solarimeter (Kipp, spectral range: $305-2800 \mathrm{~nm}$ ) and corrected for reflection and absorption of the walls of the chambers (about $12 \%$ ).

All the parameters were recorded every 5 minutes. During the first three weeks the measurements were carried out 4 to 5 days weekly, but from 8 July onwards only every second week. In the measuring period, temperatures in the chambers were changed at 24 -hour or 48 -hour intervals.

The microclimate in the crop enclosures differed in some respect from the ambient. In the enclosures, $\mathrm{CO}_{2}$ and water vapour were uniformly distributed and temperature gradients were small. Moreover, the humidity in the chamber was lower than outside because of condensation at het cooling body of the air-conditioner. This occurred especially during the night at lower transpiration rates.

\section{Calculations}

The $\mathrm{CO}_{2}$ exchange measurements (Louwerse \& Eikhoudt, 1975) were used to calculate the daily growth rate. To eliminate the effects of the response time of the equipment to rapid changes in light conditions, hourly means were used to construct lightresponse curves at both temperatures in each measuring period. The same procedure was used for the $\mathrm{CO}_{2}$ release from respiration during the night. The rate of gross photosynthesis was obtained by summing up net photosynthesis rate and mean above-ground rate of respiration during the night, assuming an equal respiration during day and night at the same temperature. From these data, light-response curves for gross photosynthesis at 12.5 and $22.5^{\circ} \mathrm{C}$ were derived.

For field conditions the actual gross photosynthesis and respiration were determined from these curves by linear interpolation using the actual hourly means of radiation and temperature. Daily gross photosynthesis, respiration, and consequently net photosynthesis were obtained by integration of these values. Finally, $\mathrm{CO}_{2}$ exchange was converted to dry matter production using a conversion factor of 0.606 , based on the measured carbon concentration in the tissue (45 \% $\pm 1 \%$ by analysis) and transfer of $\mathrm{CO}_{2}$ to $\mathrm{C}$.

Interpolation of the photosynthesis-light-response curves and respiration data of the preceding and following period was used for calculating crop photosynthesis and respiration during the days and weeks when no measurements were made. Meteorological data from a nearby station (at $2.5 \mathrm{~km}$ ) of the Wageningen Agricultural University were used as a basis. 


\section{Results}

A typical time course of the irradiance and the corresponding net photosynthesis and respiration in a particular week (26/8-30/8) at 22.5 and $12.5{ }^{\circ} \mathrm{C}$ is given in Figure $1 \mathrm{a}$ and $1 \mathrm{~b}$, respectively. From such curves throughout the growing season the response of the crop gross photosynthesis at different light intensities for both temperatures (Fig. 2a-2i) and the time course of the mean dark respiration (Fig. 3a and $3 \mathrm{~b})$ were made. The development of the gross photosynthesis at a selected irradiance $\left(600 \mathrm{~W} \mathrm{~m}^{-2}\right)$ and the leaf area index is shown in Figure 4. These figures demonstrate that there is a strong increase of canopy gross photosynthesis during the first 4 weeks (17/6-15/7) followed by a stable period (15/7-5/8), a gradual decrease till about $23 / 9$ and a strong decrease from $23 / 9-21 / 10$. This coincides with the increase and decrease of the LAI (Fig. 4). The relative effect of temperature on photosynthesis at high irradiances was highest in the beginning and at the end of the growing season (Fig. 2 and 4). There was hardly any difference in the initial slope of the photosynthesis-light-response curves between the high- and low-temperature treatments, but the low-temperature treatment levelled off sooner at the higher light intensities. There was a strong increase in dark respiration on a ground area basis at both temperatures till about $15 / 7$, followed by a smaller increase till the end of September and a rapid decrease afterwards (Fig. 3a). In the period between mid July and the end of September the dry matter of the standing crop increased from about $4000 \mathrm{~kg} \mathrm{ha}^{-1}$ to $14000 \mathrm{~kg} \mathrm{ha}^{-1}$ (Table 1). So when respiration was expressed on a total dry matter basis (Fig. 3b) it strongly decreased in this period, indicating that respiration was more correlated with the growth of the crop or a specific part of the crop than with the overall size of the standing crop.

Using the hourly ambient temperature and irradiance, the daily gross photosynthesis and respiration were calculated (see 'calculations'). The outcomes are presented in Figure 5c together with the daily mean temperature (Fig. 5a) and the daily sum of global radiation (Fig. 5b). As could be expected from Figure 2 and Figure 4 the daily gross photosynthesis during the initial period (15/6-15/7) was rapidly increasing mainly due to an increasing leaf area. After the leaf area index stabilized at about $3.5-4.0 \mathrm{~m}^{2} \mathrm{~m}^{-2}$, daily gross photosynthesis is closely related with the daily irradiation and hardly dependent on temperature. A maximum of 950 $\mathrm{kg} \mathrm{CO}_{2} \mathrm{ha}^{-1}$ day $^{-1}$ (= $576 \mathrm{~kg} \mathrm{DM} \mathrm{ha}^{-1}$ day $^{-1}$ ) is obtained on July 24 . From the beginning of September, daily gross photosynthesis decreased due to a decreasing LAI and lower levels of incoming radiation.

Figure 5c shows a rapid increase of the recalculated daily dark respiration in the initial period (15/6-15/7). From 15/7-5/10 it varied from $150-200 \mathrm{~kg} \mathrm{CO}_{2} \mathrm{ha}^{-1}$ day ${ }^{-1}$ and it closely related to the daily mean temperature, giving a maximum of $210 \mathrm{~kg} \mathrm{CO}_{2} \mathrm{ha}^{-1}$ day $^{-1}$ (=127 kg DM ha-1 day-1) on 14/7. From 5/10 onwards, respiration decreased rapidly to about $25 \mathrm{~kg} \mathrm{CO}_{2} \mathrm{ha}^{-1}$ day-1. On only six days with a low radiation and a relatively high temperature $(17 / 9,10 / 10,15 / 10-18 / 10)$ dark respiration exceeded the gross photosynthesis, resulting in a negative net photosynthesis. The difference between the cumulated dry matter yields, calculated from the $\mathrm{CO}_{2}$ fixation minus respiration, and the harvested crop is assumed to be 
Net $\mathrm{CO}_{2}$ uptake

$\left[k g h a^{-1} h^{-1}\right]$

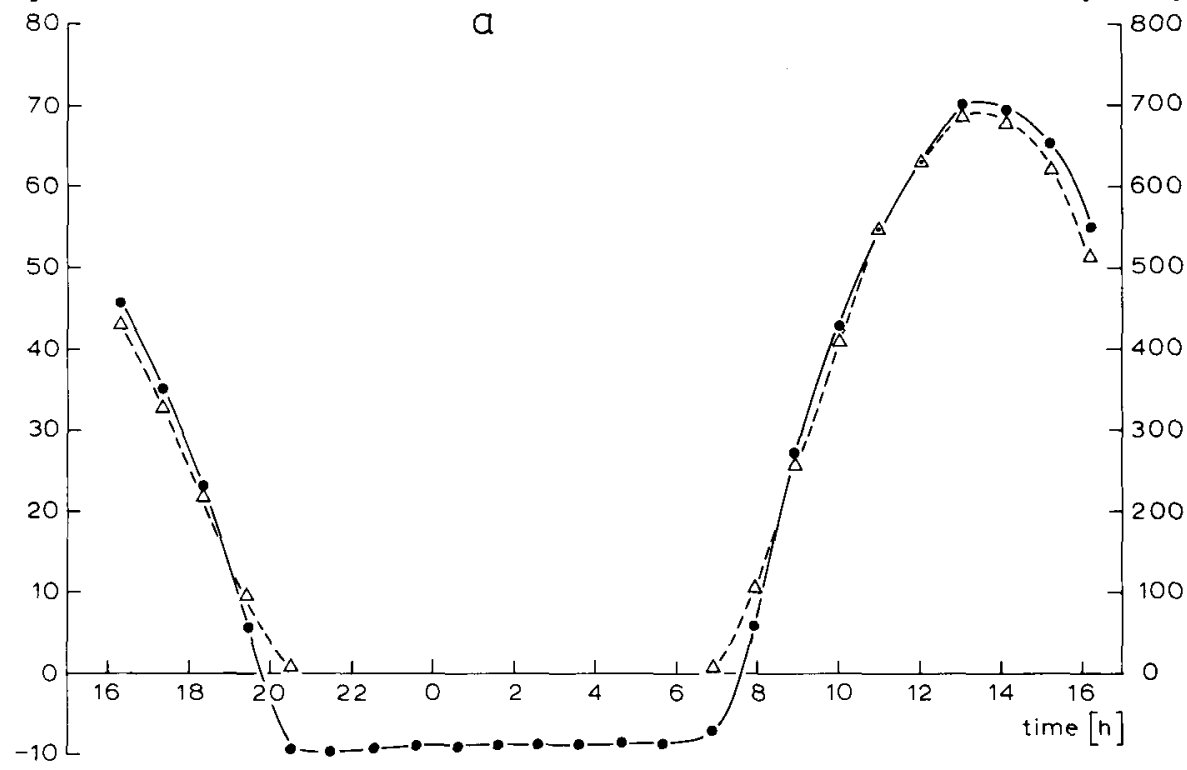

Net $\mathrm{CO}_{2}$ uptake

$\left[\mathrm{kg} \mathrm{ha}^{-1} \mathrm{~h}^{-1}\right]$

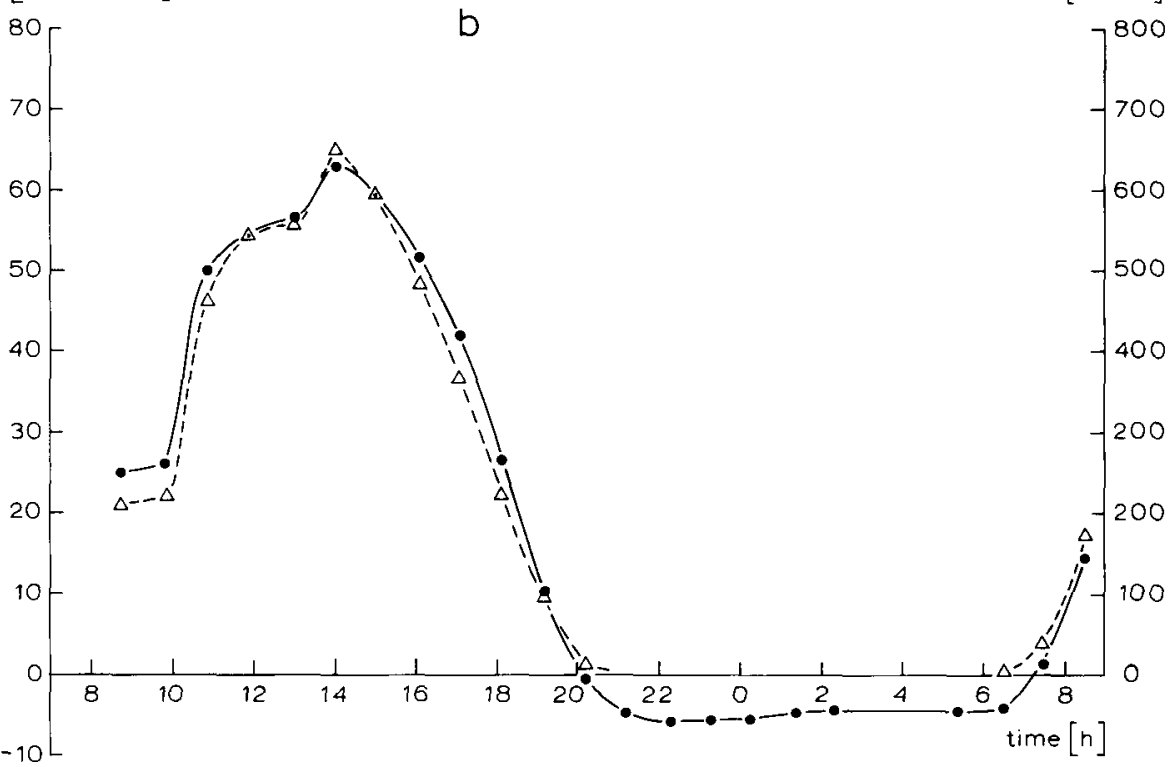

Fig. 1. Daily course of net $\mathrm{CO}_{2}$ uptake $(\bullet-\bullet)$ and irradiance $(\Delta-\Delta)$. (a) Temperature: $22.5^{\circ} \mathrm{C}$, date: 27-28 August 1985 . (b) Temperature: $12.5{ }^{\circ} \mathrm{C}$; date: 29-30 August 1985 . 


\section{W. LOUWERSE, L. SIBMA AND J. VAN KLEEF}

an estimate of the amount of assimilates translocated under the ground, where it may be used for formation of roots, respiration and exudation into the rhizosphere (Table 1). Only in the first period (19/6-2/7) processes under the ground seemed to require on the average a high fraction of the assimilates (37\% of net photosynthesis). After this period this percentage dropped to about $30 \%$ and remained constant.
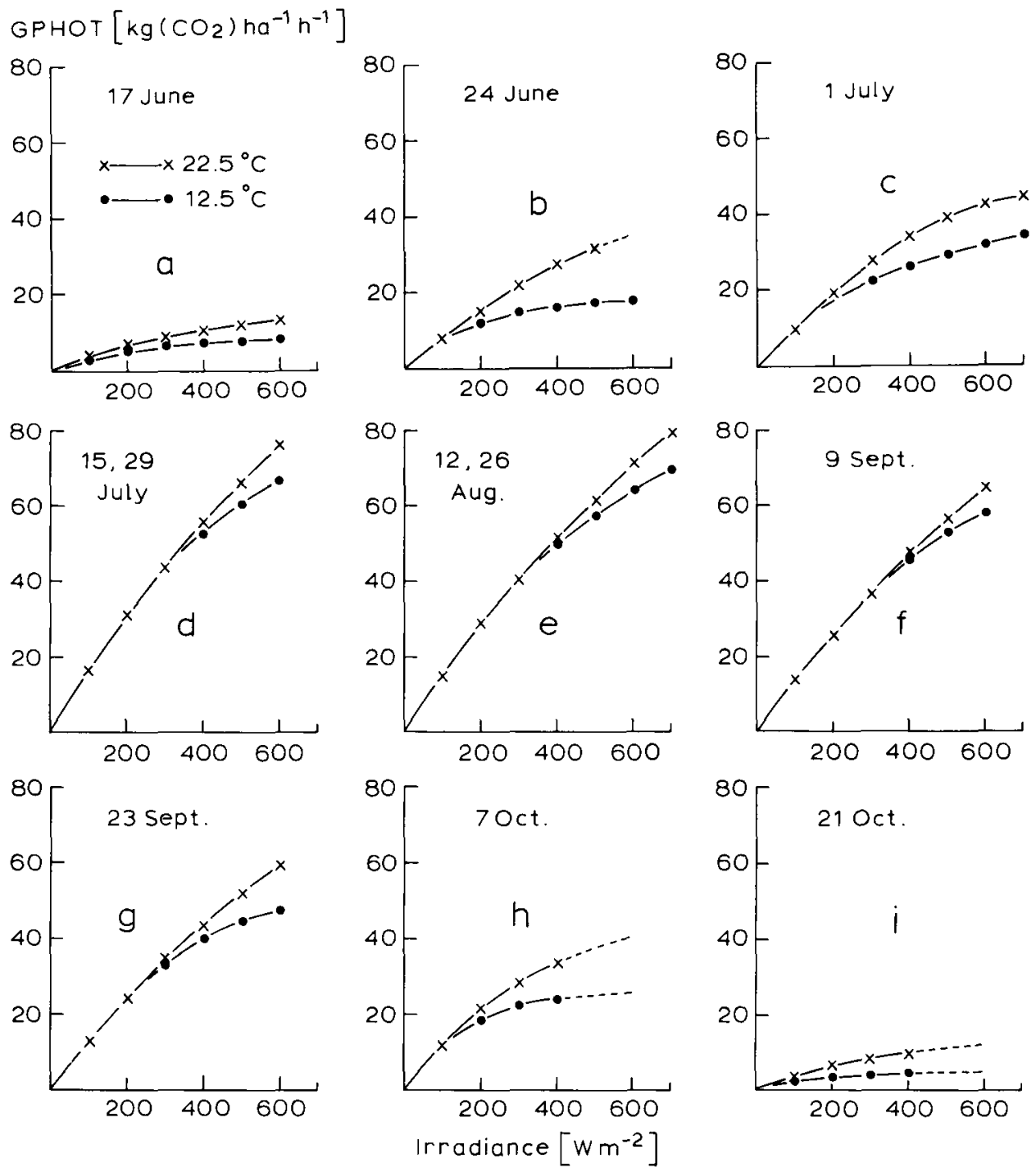

Fig. 2. Calculated rate of gross photosynthesis (GPHOT) as a function of irradiance at two temperatures at different times during the growing season (a-i) as described in 'Calculations'. The response curves at each temperature are fitted by eye from determinations with two enclosures on two days. The date indicates the first day of the measurement week. 
Respiration

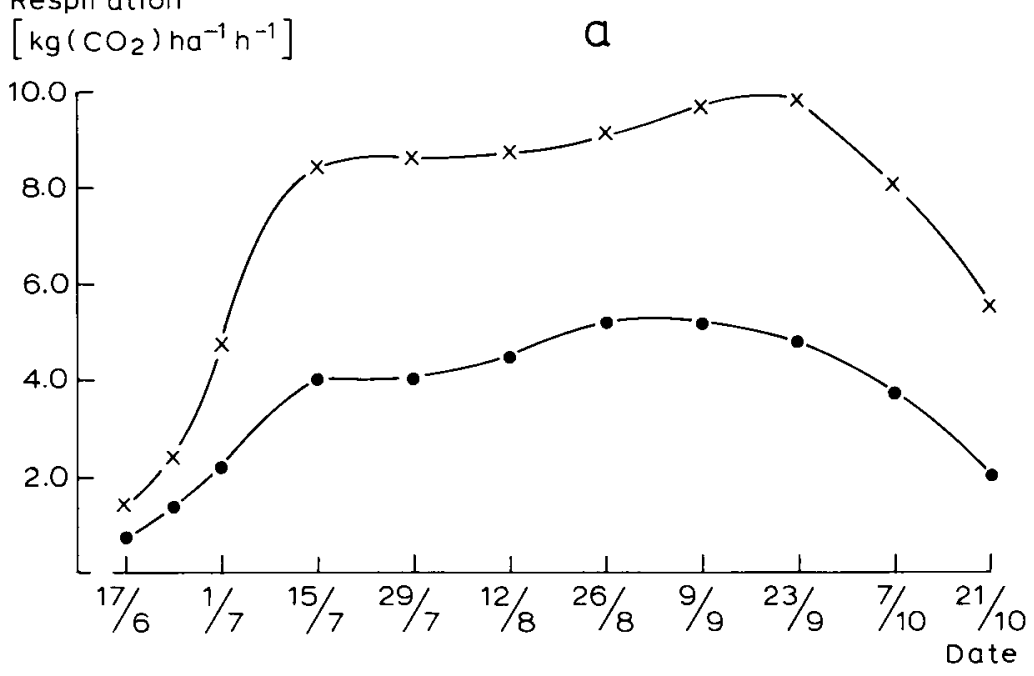

Respiration

$\left[\mathrm{g}\left(\mathrm{CO}_{2}\right) \mathrm{kg}^{-1}(\mathrm{DM}) \mathrm{h}^{-1}\right]$

$b$

${ }^{4.0}$
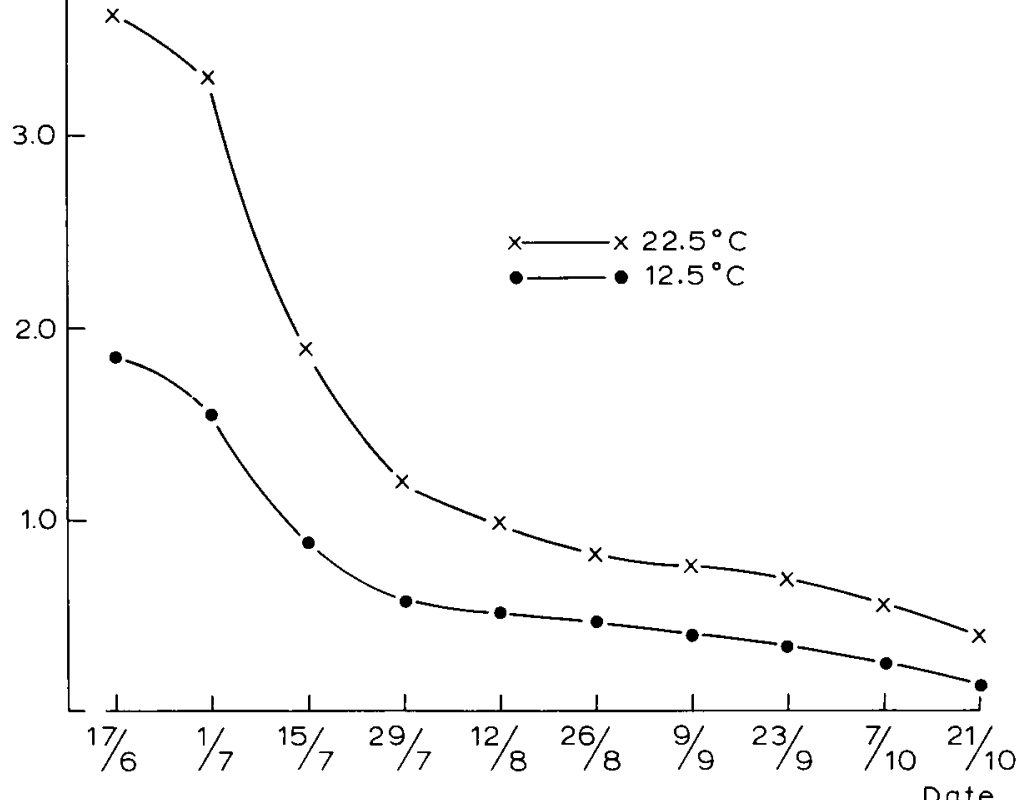

Fig. 3. Mean dark respiration rate of the above-ground parts at two temperatures $\left(12.5\right.$ and $\left.22.5{ }^{\circ} \mathrm{C}\right)$ as a function of time. The date indicates the first day of the measurement week. Every symbol is the mean of determinations with two enclosures on two days. (a) Expressed on a ground-area basis. (b) Expressed on a total dry matter basis. 


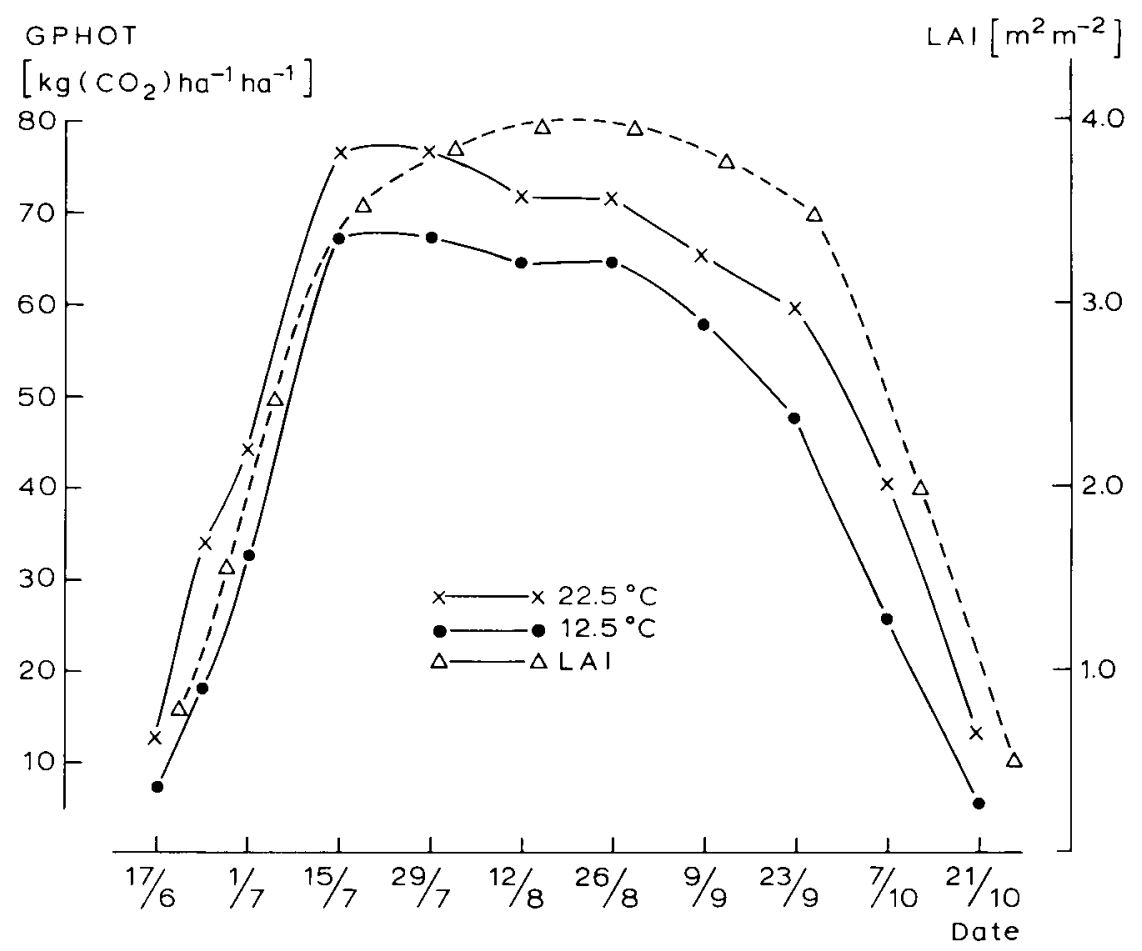

Fig. 4. Gross photosynthesis rate (GPHOT) at two temperatures at an irradiance of $600 \mathrm{~W} \mathrm{~m}^{-2}$ and the leaf area index (LAI) as a function of time.

\section{Discussion}

It is well documented that the rate of photosynthesis of $\mathrm{C}_{4}$ plants at ambient $\mathrm{CO}_{2}$ levels (at present about $350 \mu 1^{1-1}$ ) is highly sensitive to temperature. Taylor \& Rowley (1971) found a reduction in rate of photosynthesis of $90 \%$ (after one day; later even more) when the temperature was lowered from $25^{\circ} \mathrm{C}$ to $10^{\circ} \mathrm{C}$. Comparable results were reported by Charles-Edwards \& Charles- Edwards, 1970; Hofstra \& Hesketh, 1969; van Laar \& Penning de Vries, 1972; and Raschke, 1970. Plants subjected to such temperature changes also showed a large after-effect when temperature was restored to initial values (Taylor \& Rowley, 1971). This is in contrast with our findings, where only in the early stages (till July, Fig. 2a-2c) and very late stages (after the end of September, Fig. 2h-2i) a reduction of about $50 \%$ at the higher light intensities was measured. In the period of major dry matter production (mid July until the beginning of September) this temperature effect was only $12-15 \%$ at the higher light intensities (occurring only at midday). It may be suggested that light saturation is required to yield a maximum difference in response to changes in temperature. Lower leaf-layers in the canopy would therefore give only a limited 
Table 1. Calculated cumulative values of gross photosynthesis (GPHOT) (a), above-ground respiration (resp.) (b), net photosynthesis (NPHOT) (a-b), harvested standing biomass (c) and assimilate transport into the soil (a-b-c); all expressed in $\mathrm{kg} \mathrm{DM} \mathrm{ha}^{-1}$. Standing biomass has been corrected for initial biomass on 19/6 (393 $\left.\mathrm{kg} \mathrm{ha}^{-1}\right)$. Above-ground respiration, standing biomass and assimilate transport into the soil are expressed as $\%$ of gross photosynthesis and net photosynthesis (standing biomass and assimilate transport only).

\begin{tabular}{|c|c|c|c|c|c|c|c|c|c|c|}
\hline \multirow[t]{2}{*}{ Date } & \multicolumn{5}{|c|}{ Dry matter $\left(\mathrm{kg} \mathrm{ha}^{-1}\right)$} & \multicolumn{3}{|c|}{$\%$ of GPHOT } & \multicolumn{2}{|c|}{$\%$ of NPHOT } \\
\hline & $\begin{array}{l}\text { GPHOT } \\
\text { (a) }\end{array}$ & $\begin{array}{l}\text { RESP } \\
\text { (b) }\end{array}$ & $\begin{array}{l}\text { NPHOT } \\
\text { (a-b) }\end{array}$ & $\begin{array}{l}\text { biomass } \\
\text { (c) }\end{array}$ & $\begin{array}{l}\text { soil } \\
(a-b-c)\end{array}$ & RESP & biomass & soil & biomass & soil \\
\hline $19 / 6-2 / 7$ & 1762 & 349 & 1413 & 882 & 531 & 19.8 & 50.1 & 30.1 & 62.4 & 37.6 \\
\hline $16 / 7$ & 6593 & 1374 & 5219 & 3717 & 1502 & 20.8 & 56.4 & 22.8 & 71.2 & 28.8 \\
\hline $30 / 7$ & 11769 & 2616 & 9153 & 6382 & 2771 & 22.2 & 54.2 & 23.5 & 69.7 & 30.3 \\
\hline $13 / 8$ & 16761 & 3728 & 13033 & 8647 & 4386 & 22.2 & 51.6 & 26.2 & 66.3 & 33.7 \\
\hline $27 / 8$ & 21095 & 4927 & 16168 & 11142 & 5026 & 23.4 & 52.8 & 23.8 & 68.9 & 31.1 \\
\hline $10 / 9$ & 24992 & 6111 & 18881 & 12432 & 6449 & 24.5 & 49.7 & 25.8 & 65.8 & 34.2 \\
\hline 24.9 & 27558 & 7395 & 20163 & 14325 & 5838 & 26.8 & 52.0 & 21.2 & 71.0 & 29.0 \\
\hline $8 / 10$ & 29934 & 8515 & 21419 & 14777 & 6642 & 28.4 & 49.4 & 22.2 & 69.0 & 31.0 \\
\hline $15 / 10$ & 30456 & 8829 & 21627 & 14995 & 6631 & 29.0 & 49.2 & 21.8 & 69.3 & 30.7 \\
\hline $22 / 10$ & 30695 & 9023 & 21672 & 15567 & 6105 & 29.4 & 50.7 & 19.9 & 71.8 & 28.2 \\
\hline
\end{tabular}

response to temperature. However, since a major part of the assimilate production is realized in the top layers, such an effect would not fully explain our results. Apparently the growth stages in which the plants are most sensitive to temperature regarding their photosynthesis, are leaf formation and senescence.

This observation may be the explanation for the detected high sensitivity to temperature, often found in laboratory experiments. In general these experiments have been carried out with young plants ( $20-40$ days), where leaves were not fully mature. Extrapolation of these data in simulation models to the whole growing period and to field situations may therefore be misleading. Net photosynthesis in the period from mid July until mid September, as the major increase in dry matter takes place, will hardly be affected by lower temperatures, as photosynthesis is only slightly lower and dark respiration will also decrease (Figs. 2 and 3a).

During the first growing period (17/6-15/7), dry matter of the above-ground biomass increased from 882 to $3717 \mathrm{~kg} \mathrm{DM} \mathrm{ha}^{-1}$ (Table 1) and respiration rate from 1 to $8 \mathrm{~kg} \mathrm{ha}^{-1} \mathrm{~h}^{-1}$ (Fig. 3a). From mid July until the end of August, however, the dry matter of the standing crop increased from $4000 \mathrm{~kg} \mathrm{ha}^{-1}$ to $14600 \mathrm{~kg} \mathrm{ha}^{-1}$, while respiration increased only from 8.4 to $9.7 \mathrm{~kg} \mathrm{CO}_{2} \mathrm{~kg} \mathrm{ha}^{-1} \mathrm{~h}^{-1}$. This demonstrates that not only the amount but also the quality of living tissue determines the respiration rate.

The data from periodical harvests were used to quantify carbon utilization (growth and maintenance respiration) of the growing crop. Growth respiration was calculated using coefficients from Penning de Vries et al. (1989). The conversion costs for leaves, stems and cobs + grain were $0.46,0.41$ and $0.38 \mathrm{~g} \mathrm{CO}_{2}$ per $\mathrm{g}$ synthesized dry matter respectively. Maintenance respiration was calculated at 12.5 and 


\section{W. LOUWERSE, L. SIBMA AND J. VAN KLEEF}
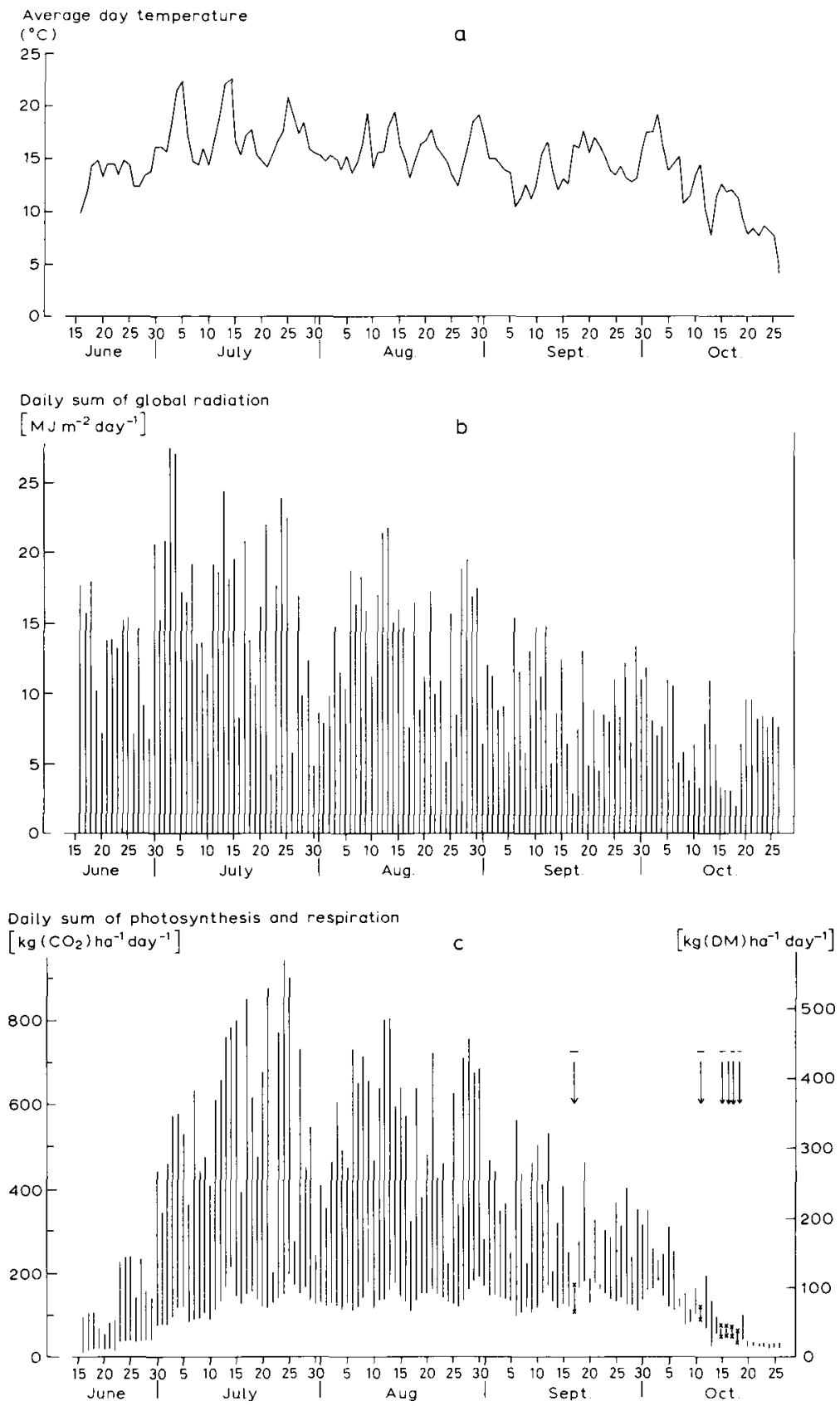

Fig. 5. Seasonal pattern of (a) daily mean temperature (hourly basis) (b) daily global radiation and (c) daily sum of photosynthesis and respiration. The calculated daily gross photosynthesis (top of bar), net photosynthesis (bar length) and respiration (lower end of bar) are expressed as $\mathrm{CO}_{2}$ (left) and dry matter (right). The arrows in (c) indicate days with a negative daily net photosynthesis. 


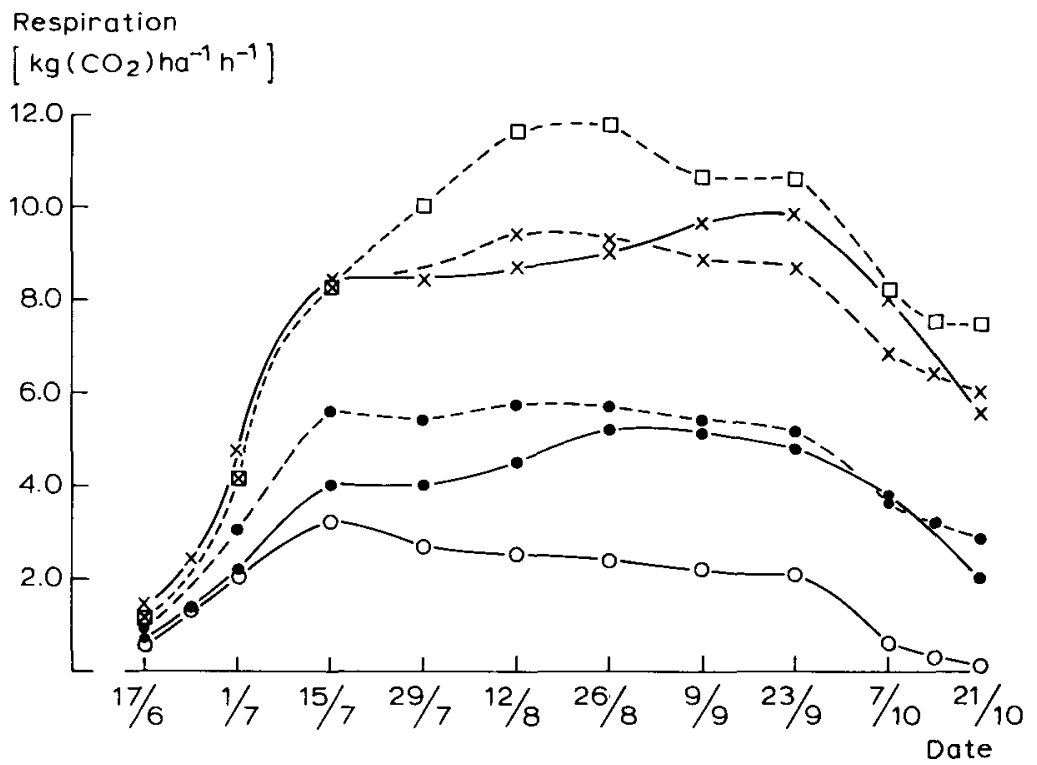

Fig. 6. Measured dark respiration at $12.5^{\circ} \mathrm{C}(\bullet-\bullet)$ and $22.5^{\circ} \mathrm{C}(\times-\times)$ and calculated growth + maintenance respiration at $12.5^{\circ} \mathrm{C}(\bullet-\bullet)$ and $22.5^{\circ} \mathrm{C}(x-x)$ as a function of time, assuming a maximum maintenance respiration for stems (at a yield of $2500 \mathrm{~kg} \mathrm{DM} \mathrm{ha}^{-1}$ ) and for cobs and grains (at a yield of $1000 \mathrm{~kg} \mathrm{DM} \mathrm{ha}^{-1}$ ) or a maximum maintenance respiration for cobs + grains only ( $\mathrm{c--}$ - ) at $22.5^{\circ} \mathrm{C}$. Growth respiration $(\mathrm{o}-\mathrm{o})$ was calculated from the increase in crop dry weight during the experimental period.

$22.5^{\circ} \mathrm{C}$, also using maintenance coefficients from Penning de Vries et al. (1989) (leaves 0.04 , stems 0.015 and cobs and grain $0.015 \mathrm{~g} \mathrm{CO}_{2} \mathrm{~g}^{-1} \mathrm{DM}$ day-1 at $20{ }^{\circ} \mathrm{C}$; $\mathrm{Q}_{10}=2.0$ ). There is much evidence (Sibma, 1987) that beyond a dry matter amount in cobs exceeding $1000 \mathrm{~kg} \mathrm{ha}^{-1}$ the amount of proteins and minerals in the cob biomass no longer increases, and mainly starch is stored. Starch will require hardly any energy for maintenance. In our calculations the maintenance respiration for cobs was therefore kept constant for the period that the dry matter in cobs exceeded that amount (from 30/7 onwards).

Doing so, the sum of growth and maintenance respiration calculated in the initial growth period (until mid July) matches fairly well the measured dark respiration at $22.5^{\circ} \mathrm{C}$ (Fig. 6). After this period however, the calculated value is much higher than the actual respiration. According to Sibma (1987) also the total amounts of nitrogen and minerals in stems hardly increase after mid July (dry matter of stems is about $2500 \mathrm{~kg} \mathrm{ha}^{-1}$ ). This would imply that maintenance respiration would also become constant. Using this, correspondence between calculated and measured values is improved (Fig. 6).

Total dark respiration at $12.5^{\circ} \mathrm{C}$, calculated from growth and maintenance respiration with the same assumptions as at $22.5^{\circ} \mathrm{C}$, was overestimated during the first growing period compared with the measured values. This deviation may be related 
to changed properties of the plants grown at lower temperatures during this period. It may also be hypothesized that part of the assimilates, produced at the lower temperature, was not converted into structural dry matter, thereby reducing conversion costs. Within the relatively short measuring period at these temperatures (24-48 $h$ ), an eventual feed-back reaction of the rate of assimilation could however not be observed.

From the total amount of $\mathrm{CO}_{2}$ absorbed by the crop, corresponding with $30.7 \mathrm{t}$ DM ha-1, 30\% is lost by above-ground respiration, and $50 \%$ is invested in above-ground biomass (Table 1). The remaining $20 \%$ is assumed to be transported under the ground. Only at the start of growth, investment in the roots may amount to some $30 \%$ of gross photosynthesis (Table 1). In general, literature reports claim a much higher proportion of the gross photosynthesis to be translocated to plant parts under the ground. Merckx et al. (1989) found in laboratory experiments with wheat and maize that about $50 \%$ of net photosynthesis (about $35 \%$ of gross photosynthesis) is transported to the roots. Similar results were obtained by Barber \& Martin (1976) with wheat plants, where $43-50 \%$ of the net photosynthesis was transported to the roots. This difference might be due to the fact that these laboratory experiments were done with relatively young plants ( 3 - 6 weeks) with sometimes very high root/shoot-ratios (up to 0.8 ). This ratio is much lower in older plants (Brouwer, 1966), with a consequent smaller demand for assimilates. This is confirmed in the experiments of Keith et al. (1986), who found a decreasing proportion of the ${ }^{14} \mathrm{CO}_{2}$ fixed by wheat plants to be transported to the roots as plants mature and age.

Sauerbeck et al. (1975) found in wheat plants that about $25 \%$ of the total amount of assimilated $\mathrm{CO}_{2}\left(=6000 \mathrm{~kg} \mathrm{DM} \mathrm{ha}^{-1}\right)$ transported to the soil, is still present as living roots at harvest. The remaining part $(75 \%)$ has been lost by respiration, exudation and decay of roothairs and roots. These results agree with those of Schäfer et al. (1984). Using this ratio with our data implies that from the $6000 \mathrm{~kg} \mathrm{DM} \mathrm{ha-1}^{-1}$ (Table 1) transported to the soil, about $25 \%$ (1500 $\mathrm{kg} \mathrm{DM} \mathrm{ha}^{-1}$ ) should be present as living roots at harvest. In our experiments root mass was not determined, but values between 1200 and $1500 \mathrm{~kg} \mathrm{DM} \mathrm{ha}^{-1}$ have been reported for maize (Sibma, 1987).

From 10/9 onwards there is hardly any export of photosynthates to the roots (Table 1). So from that time all net $\mathrm{CO}_{2}$ uptake will be invested in above-ground material and root respiration will take place at the expense of the roots itself.

From the results of the measurements and calculations it may be concluded that the sensitivity of maize crop photosyntesis to changes in ambient temperature may be dependent upon the growth stage of the maize plant. Even though the present experiments were not aiming at a precise determination of the respiration of different plant parts, it is very clear that there is no proportionality between standing biomass and respiration.

Such a proportionality is mostly taken as a basis for calculations in simulation models, which consequently will overestimate losses by maintenance respiration.

The present experiments lead to the conclusion that the risk of substantcial losses of dry matter at the end of the growing season is not large. Only late in the season 
on some dull days, dark respiration will exceed photosynthesis leading to a net loss of dry matter.

\section{Acknowledgements}

The authors are much indebted to Dr M. J. Kropff and Dr S. C. van de Geijn for their helpful advice and criticism in preparing this manuscript, and to $\mathrm{Mr} \mathrm{G}$. van der Sluis and Mrs M. J. de Kock for practical assistance during the experiments.

\section{References}

Barber, D. A. \& J. K. Martin, 1976. The release of organic substances by cereal roots into the soil. New Phytology 76: 69-80.

Brouwer, R., 1966. Root growth of grasses and cereals. In: F. L. Milthorpe \& J. D. Ivens (Eds), The growth of cereals and grasses, p. 153-166. Proceedings XII th Easter School Nottingham, Buttersworth, London.

Charles-Edwards, D. A. \& J. Charles-Edwards, 1970. An analysis of the temperature response curves of $\mathrm{CO}_{2}$ exchange in the leaves of two temperate and one tropical grass species. Planta, Berlin 94: 140-151.

Duncan, W. G. \& J. D. Hesketh, 1968. Net photosynthetic rates, relative leaf growth rates, and leaf numbers of 22 races of maize grown at eight temperatures. Crop Science 8: 670-674.

Hofstra, G. \& J. D. Hesketh, 1969. Effects of temperature on the gas exchange of leaves in the light and dark. Planta, Berlin 85: 228-237.

Keith, H., J. M. Oades \& J. K. Martin, 1986. Input of carbon to soil from wheat plants. Soil Biology and Biochemistry 18: 445-449.

Laar, H. H. van \& F. W. T. Penning de Vries, 1972. $\mathrm{CO}_{2}$-assimilation light response curves of leaves; some experimental data. Verslagen Instituut Biologisch en Scheikundig Onderzoek Landbouwgewassen 62 , IBS Wageningen, $54 \mathrm{pp}$.

Louwerse, W. \& J. W. Eikhoudt, 1975. A mobile laboratory for measuring photosynthesis, respiration and transpiration of field crops. Photosynthetica 9: 31-34.

Louwerse, W., 1980. Effects of $\mathrm{CO}_{2}$ concentration and irradiance on stomatal behaviour of maize, barley and sun flower plants in the field. Plant, Cell and Environment 3: 391-399.

Merckx, R., J. H. van Ginkel, J. Sinnaeve \& A. Cremers, 1986. Plant-induced changes in the rhizosphere of maize and wheat. I. Production and turnover of root-derived material in the rhizosphere of maize and wheat. Plant and Soil 96: 85-93.

Penning de Vries, F. W. T., D. M. Jansen, H. F. M. ten Berge \& A. H. Bakema, 1989. Simulation of ecophysiological processes in several annual crops. Simulation Monographs 29. Pudoc, Wageningen, $286 \mathrm{pp}$.

Raschke, 1970. Temperature dependence of $\mathrm{CO}_{2}$ assimilation and stomatal aperture in leaf sections of Zea mays. Planta, Berlin 91: 336-363.

Sauerbeck, D., B. Johnen \& R. Six, 1975. Atmung, Abbau und Ausscheidungen von Weizenwurzeln im Laufe ihrer Entwicklung. Landwirtschaftliche Forschung, Sonderheft 32/1: 49-58.

Schäfer, W. I. Klank, E. Matthäus \& H. R. Breitmoser, 1984. $\mathrm{CO}_{2}$-Bilanz bei Winterweizen während der Vegetations-stadien $\mathrm{F}_{4}-\mathrm{F}_{19}$. Colloquia Pflanzenphysiologie der Humboldt-Universität zu Berlin 7: $285-291$,

Sibma, L., 1977. Maximization of arable crop yields in the Netherlands. Netherlands Journal of Agricultural Science 25: 278-287.

Sibma, L., 1987. Ontwikkeling en groei van maïs (Zea mays L.) onder Nederlandse omstandigheden. Gewassenreeks 1. Pudoc, Wageningen, $57 \mathrm{pp}$.

Struik, P. C., 1983. Effect of temperature on development, dry matter production, dry matter distribution and quality of forage maize (Zea mays L.). An analysis. Mededelingen Landbouwhogeschool, Wageningen, 83-3, $41 \mathrm{pp}$.

Netherlands Journal of Agricultural Science 38 (1990) 


\section{W. LOUWERSE, L. SIBMA AND J, VAN KLEEF}

Struik, P. C., B. Deinum \& J. M. P. Hoefsloot, 1985. Effects of temperature during different stages of development on growth and digestibility of forage maize (Zea mays L.) Netherlands Journal of Agricultural Science 33: 405-420.

Taylor, A. O. \& J. A. Rowley, 1971. Plants under climatic stress. I. Low temperature, high light effects on photosynthesis. Plant Physiology 47: 713-718. 